
\title{
R Reserach S Surare \\ Study On Optimization Mechanism of Thermal Recovery Efficiency Under Different Geothermal Well Layout Conditions
}

Jun-yi Gao ( $\sim$ gjynizb@qq.com )

Yan'an University

\section{Research Article}

Keywords: Geothermal well, Different geothermal well layout, Thermal recovery efficiency, Optimization study

Posted Date: August 5th, 2021

DOI: https://doi.org/10.21203/rs.3.rs-744981/v1

License: (c) (1) This work is licensed under a Creative Commons Attribution 4.0 International License.

Read Full License 
Study on optimization mechanism of thermal recovery efficiency under different geothermal well layout conditions

$$
\text { Jun-yi Gao }{ }^{1,2}
$$

${ }^{1}$ School of Architecture and Civil Engineering, Yan' an University, Yan' an 716000, China;

${ }^{2}$ Shandong Provincial Lunan Geology and Exploration Institute, Jining 272100, China

*Corresponding author: Junyi Gao E-mail: gjynizb@qq.com

\section{Abstract}

Efficient exploitation of geothermal energy is a hot issue concerned by scientific and engineering circles. The layout of different injection wells and production wells directly affects the temperature field of production wells and rock mass. In order to study the thermal recovery efficiency under different geothermal well layout conditions, based on the conceptual model of two injection wells and two production wells, a 3DEC program is used to calculate and analyze the influence of the different water inlet and water inlet of two injection wells and two production wells on the temperature field of rock mass, geothermal wells and the water temperature of production wells outlet. The results show that: (1) After the model injection wells are switched with the production wells, the temperature gradients of rock mass, production wells and injection wells are almost the same in numerical value and opposite in direction. (2)Production wells are set on the left side and injection wells are set on the right side of the model, and the injection wells and production wells are set at intervals; The temperature field of rock mass on both sides of the edge forms a central symmetry; The temperature gradient of rock mass from the middle to the edge is smaller and smaller, which indicates that the heat transfer speed of rock mass from the middle to the edge is slower and slower. Because the thermal superposition of adjacent injection wells and production wells through the rock mass between them is dominant, the water temperature at the outlet of production wells is the highest; In the interval water injection well and production well, the heat convection between water flow and rock is dominant, which makes the water temperature of production well outlet drops. (3) According to the water temperature at the outlet of production well, the optimal order of the model is working condition $3>$ working condition $1=$ working condition $2>$ working condition 4 , and the time to reach a steady state is the shortest in working condition 3 and the longest in working condition 4 . The research results can provide important theoretical and practical reference for optimizing the layout of geothermal wells in efficient geothermal exploitation.

Keywords: Geothermal well, Different geothermal well layout, Thermal recovery efficiency, Optimization study

\section{Introduction}

In the process of geothermal exploitation, if the limited groundwater resources around the geothermal well can not replenish pumping capacity through runoff, it is necessary to consider the injection well to replenish the pumping capacity of production well in time, so as to achieve the dynamic balance between pumping capacity and injection capacity, and so as to realize the sustainable geothermal exploitation. The underground hot water can be used for heating and generating power after being pumped to the ground. It is found that the geothermal water extraction system is not only affected by the groundwater flow field and temperature field, but also by the layout of geothermal wells and many other factors. Under the combined effect of these factors, how to scientifically and reasonably arrange injection wells and production wells has a great impact on the temperature field of rock mass near the production wells and well groups.It is 
of great engineering significance to study the wellbore temperature field in the exploration and development of geothermal resources (Yu 2013; Wang et al. 2018; Wen et al.2007).

At present, the research on geothermal well temperature mainly focuses on numerical simulation analysis. Many scholars have carried out research on the influencing factors of fluid, rock temperature field and wellbore temperature (Wu et al. 2014), research on the influence of groundwater flow velocity in sandy aquifer on the thermal performance of borehole heat exchanger (Angelotti et al. 2014), three-dimensional thermo-poroelastic modeling and analysis of flow, heat transport and deformation in fractured rock with applications to a lab-scale geothermal system (Gao and Ghassemi 2020) and numerical simulation analysis on the influence of different factors on the thermal distribution around wellbore (Rees et al. 2013). Groundwater flow estimation for temperature monitoring in borehole heat exchanger during thermal response test (Yoshioka et al. 2018), heat extraction analysis of a novel multilateral-well coaxial closed-loop geothermal system (Wang et al. 2021) and research on the influence of borehole heat-water exchanger characteristics on the performance of vertical closed-loop ground heat pump system were carried out (Dehkordi et al. 2014). The influence mechanism of geothermal well spacing, geothermal temperature and production well depth on water flow and heat transfer temperature of rock mass was studied (Gao Junyi 2020), but the literature did not consider the influence of the interaction of injection wells and production wells on the temperature field of production wells and rock mass. Research on outlet temperature and temperature field of geothermal well ( $\mathrm{Li}$ et al. 2014; Shen 2015; Wang et al. 2015; Wang et al. 2018), sensitivity analysis of influencing factors for heat loss of geothermal wells (Zhu et al. 2015), and wellbore temperature loss model and application for heating geothermal mining (Dou 2019). However, the research contents of these scholars did not involve the comparative study of water temperature and temperature field at the outlet of geothermal wells under different conditions of water inlet and water outlet. Scholars have carried out the influence of pumping and irrigation well layout on groundwater flow field and temperature field (Wang et al. 2016), the influence of pumping and irrigation well distribution mode and pumping and irrigation well water quantity on heat transfer characteristics of underground heat exchanger wells (Ma et al. 2019, 2020), and the application of numerical simulation of water and heat transport to optimize pumping and irrigation well layout of groundwater source heat pump system (Jin et al. 2012), Numerical simulation of water-heat coupling of single well ground water source heat pump in T2Well ( $\mathrm{Li} u$ et al. 2020) and optimization of reasonable well spacing and layout of shallow source heat pump simulated by sand tank-taking Jiuxi in Fenglin as an example (Ma et al. 2018). Scholars have carried out sustainable electricity generation from an Enhanced Geothermal System considering reservoir heterogeneity and water losses with a discrete fractures model(Joël et al. 2021), Enhanced Geothermal Systems (EGS): hydraulic fracturing in a thermo-poroelastic framework (Loret 2019) and modified zipper fracturing in enhanced geothermal system reservoir and heat extraction optimization via orthogonal design(Yu et al. 2020). To sum up, although some achievements have been made in the study of geothermal well temperature, there are few reports on the complex model of thermal recovery efficiency optimization under different geothermal well layout conditions. The actual geothermal mining process is closely related to the scientific and reasonable layout of geothermal wells. The influence of different geothermal well layout conditions on the temperature field of production wells and rock mass is directly related to the safety and efficiency of geothermal mining. In view of this, it is very necessary to carry out research on optimization of 
thermal mining efficiency under different geothermal well layout conditions.

In this paper, firstly, the fractured rock mass models of four injection wells and production wells are constructed by 3DEC discrete element software; Then, the influence of different water inlet and water outlet on the temperature field of production well and rock mass and the water temperature of production well outlet are calculated under different geothermal well layout conditions; Finally, through the comparative analysis of the calculation results, the law of the influence of different geothermal well layout on the rock mass water flow and heat transfer temperature is revealed.

\section{Conceptual model of geothermal exploitation}

Fig. 1 is a schematic diagram of geothermal resources exploitation. Four water injection wells and water output wells were drilled from the ground by using mechanical drills, and the hot rock area at the bottom of the water injection wells and water output wells was mechanically fractured to form a micro-joint system to open the fracture channel between the water injection well and the bottom of the water outlet well. The ground injected low temperature water into the water injection well, and the water flowed into the bottom through injection well. The hot water is stored in the artificial heat reservoir area through convection and heat transfer with high temperature hot rock, and the high temperature water is pumped out to the ground through the well for comprehensive utilization such as power generation and heat. In this paper, only four injection wells and production wells are considered, and engineering fracture systems are ignored.

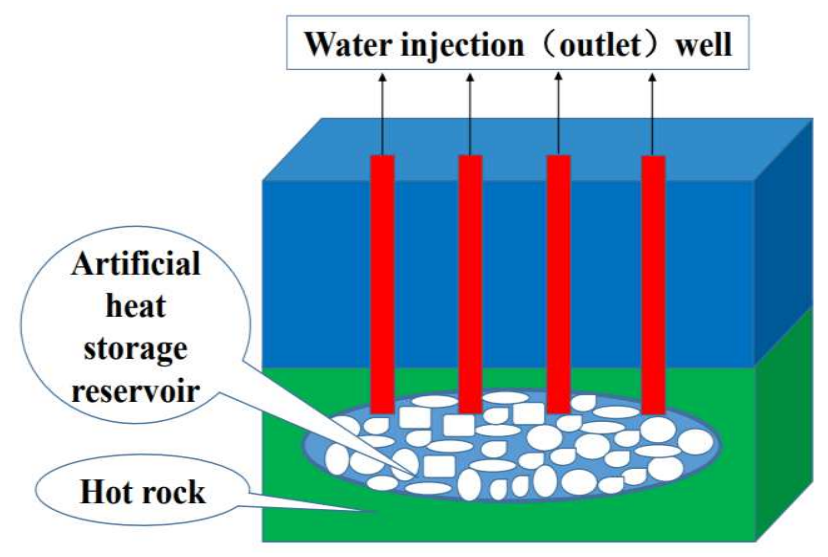

Fig. 1 A schematic diagram of geothermal resources exploitation

\section{Establishment of numerical model}

\section{Basic assumptions of the model}

Three components of heat flux and temperature reflect heat conduction variables in 3DEC. The energy balance equation and Fourier law of heat conduction are related to these variables. The differential equation of heat conduction is obtained by combining Fourier law with energy balance equation. According to specific geometry and properties, the differential equation can be solved under specific boundary and initial conditions. The following dimensionless numbers are used to characterize transient heat conduction.

Characteristic length:

$$
L_{c}=\frac{V_{s}}{A_{s}}
$$

here the volume of solid is expressed by $V_{s}\left[\mathrm{~m}^{3}\right]$; The surface area of heat exchange is expressed 
by $A_{S}\left[m^{2}\right]$.

Thermal diffusivity:

$$
\kappa=\frac{k}{\rho c_{V}}
$$

here $k$ is the thermal conductivity $\left[\mathrm{W} /\left(m \cdot{ }^{\circ} \mathrm{C}\right)\right] ; \rho$ is the density; $C_{v}$ is the specific heat at constant volume $\left[\mathrm{J} / \mathrm{kg} \cdot{ }^{\circ} \mathrm{C}\right]$.

Characteristic time:

$$
t_{c}=\frac{L_{C}^{2}}{\kappa}
$$

The differential expression of the energy balance has the form:

$$
-q_{i, i}+q_{V}=\frac{\partial \zeta}{\partial t}
$$

here $q_{i, i}$ is the heat-flux vector $\left[\mathrm{W} / \mathrm{m}^{3}\right] ; q_{v}$ is the volumetric intensity of heat-source intensity $\left[\mathrm{W} / \mathrm{m}^{3}\right]$; and $\zeta$ is the heat stored per unit volume in $\left[\mathrm{J} / \mathrm{m}^{3}\right]$.

In general, change of temperature may be caused by variation in both energy storage and volumetric strain $\varepsilon$. And the constitutive thermal lawrelating those parameters may be expressed as:

$$
\frac{\partial T}{\partial t}=M_{t h}\left(\frac{\partial \zeta}{\partial t}-\beta_{t h} \frac{\partial \varepsilon}{\partial t}\right)
$$

here $M_{t h}$ and $\beta_{t h}$ are material constants; $T$ represents the temperature.

For this law, a particular case of $\beta_{t h}=0$ and $M_{t h}=\frac{1}{\rho c_{V}}$ was considered, in which $\rho$ is the mass density of the medium $\left[\mathrm{kg} / \mathrm{m}^{3}\right]$, and $C_{v}$ is the specific heat at constant volume $\left[\mathrm{J} / \mathrm{kg} \cdot{ }^{\circ} \mathrm{C}\right]$.The change of strain was assumed to play a minor role in influencing the temperature-valid for quasi-static mechanical problems involving solids and liquids.

$$
\frac{\partial \zeta}{\partial t}=\rho C_{V} \frac{\partial T}{\partial t}
$$

By substituting Eq. (6) into Eq. (4), the energy-balance equation was yields

$$
-q_{i, i}+q_{V}=\rho C_{V} \frac{\partial T}{\partial t}
$$

It needs to be noted that for all solids and liquids, the specific heats at constant pressure and at constant volume are essentially equal. Consequently, $C_{v}$ and $C_{p}$ can be used interchangeably.

According to the finite-difference approximation principle of spatial derivatives, the numbers from 1 to 4 represent each node of the tetrahedron, the opposite side of node $n$ is face $n$, and the value of the superscript (f) is related to the relevant variable on the face $f$.

The temperature changes linearly in the tetrahedron; The temperature gradient is represented by the node value of temperature according to Gauss divergence theorem: 


$$
T,_{j}=-\frac{1}{3 \mathrm{~V}} \sum_{l=1}^{4} T^{l} n_{j}^{(l)} S^{(l)}
$$

here the external unit vector perpendicular to the surface $l$ is denoted by $[n]^{(l)}$, the surface area is denoted by $S$, and the tetrahedral volume is denoted by $V$ 。

Energy-balance equation formula of nodes.The energy-balance Eq. (7) may be expressed as:

$$
q_{i, i}+b^{*}=0
$$

where

$$
b *=\rho C_{V} \frac{\partial T}{\partial t}-q_{V}
$$

is the instantaneous "physical strength" in the mechanical node formula. Using a tetrahedron analogy, the nodal heat $Q_{e}^{n}[w] \quad \mathrm{n}=1,4$ in equilibrium with its heat flux and body force can be expressed as:

$$
Q_{e}^{n}=Q_{t}^{n}-\frac{q_{v} V}{4}+m^{n} C_{v}^{n} \frac{\mathrm{d} T^{n}}{d t}
$$

where

$$
Q_{t}^{n}=\frac{q_{i} n_{i}^{(n)} S^{(n)}}{3}
$$

and

$$
m^{n}=\frac{\rho V}{4}
$$

In theory, the node form of the energy-balance equation requires that at each global node, the sum of equivalent node heat ( ) of all tetrahedrons at the node and the node contribution ( ) of the applied boundary flux and source are zero.

Heat convection mathematical model

In the convection logic, it is assumed that fluid flow occurs within the saturated fractures, and the rock matrix is impermeable to fluid flow. Heat can be transported by the fluid convection by the fluid, and by conduction and rock conduction, as described in the previous section. The fluid has its temperature which is generally different from the rock. Heat transfer between the fracture fluid and the contacting rock (fluid-thermal coupling) may take place according to Newton's law of cooling. By coupling to heat transfer within the rock, the logic for heat transfer within the fluid is presented as follows.

Heat convection in the flow planes is described by the following equations. Heat is transported by conduction in the fracture fluid, according to Fourier's law:

$$
q_{f}^{T}=-k_{f}^{T} \Delta T
$$

here $q_{f}^{T}$ is specific heat flux in the fluid, and $k_{f}^{T}$ is fluid thermal conductivity. The energy-balance equation for the fluid obeys the equation. 


$$
\rho_{f} c_{f} \frac{\partial T_{f}}{\partial t}+\nabla \cdot q_{f}^{T}+\rho_{f} c_{f} q^{f} \cdot \nabla T_{f}+A_{f} h\left(T_{f}-T_{s}\right)=0
$$

here $\rho_{f} c_{f}$ is fluid density times specific heat; $q^{f}$ is specific fluid discharge; $A_{f}$ is contact area per unit fluid volume; $h$ is fluid/rock heat transfer coefficient; and $T_{f}, T_{s}$ are the temperature of the fluid and solid block, respectively.

For the solid blocks, the fluid flow was neglected; transport of heat obeys Fourier's law as follows:

$$
q^{T}=-k^{T} \Delta T
$$

here $q^{T}$ is specific heat flux, and $k^{T}$ is rock thermal conductivity. The energy balance is

$$
\rho_{s} c_{s} \frac{\partial T_{S}}{\partial t}+\nabla \cdot q_{s}^{T}-A_{s} h\left(T_{f}-T_{s}\right)=0
$$

here $\rho_{\mathrm{s}} c_{S}$ is solid density times specific heat; and $A_{s}$ is contact area per unit volume of solid

(from the aspect of fluid, there is contact on two sides: $A_{s}^{+}, A_{S}^{-}$, and $A_{s}=A_{S}^{+}+A_{S}^{-}$).

\section{Example model}

In this paper, it is assumed that there is a hot rock with well developed fractures in Northwest China, which has a huge heat reserve, but is relatively deficient in groundwater resources. Therefore, it is considered to inject water and effluent at the same time to maintain the sustainability of geothermal exploitation and provide long-term exploitation for local enterprises. Considering the hydrothermal heat storage at about $100 \mathrm{~m}$ underground, the low temperature geothermal resources less than $90^{\circ} \mathrm{C}$ are used for heating and technological process. In the process of geothermal exploitation, the interaction between the injection well and production well affects the water temperature distribution at the outlet of the production well and the temperature of rock mass. In this paper, it is assumed that there are four geothermal wells in the model, and the optimization mechanism of thermal recovery efficiency under different geothermal well layouts conditions was studied. The model size was $10 \mathrm{~m}$ [length] $\times 5 \mathrm{~m}$ [width] $\times 12 \mathrm{~m}$ [height], and the spacing between geothermal wells was set at $2 \mathrm{~m}$. The boundary conditions were as follows: the inlet unit temperature of production well is set as geothermal temperature, the outlet unit is set as free temperature, the inlet unit temperature of injection well was set as normal temperature, the outlet unit was set as free temperature, and the other sides were adiabatic. The surrounding rock temperature was about $20^{\circ} \mathrm{C}$ at $-100 \mathrm{~m}$ above the ground, and the model assumed that the initial water temperature of the rock and injection well was $20^{\circ} \mathrm{C}$. The numerical model size and grid division of optimization study on thermal recovery efficiency under different geothermal well layout conditions were shown in Fig. 2. In this paper, fractures $V_{1} 、 V_{2} 、 V_{3}$ and $V_{4}$ are simulated in four geothermal wells. 


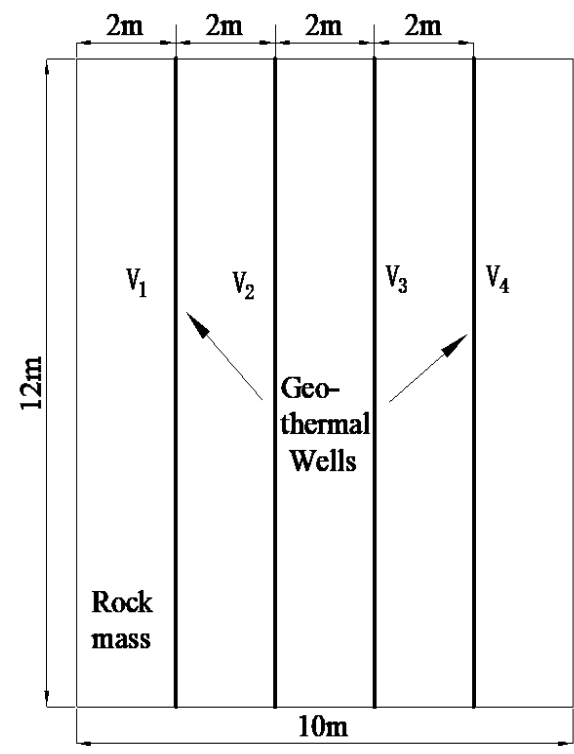

(a) Geothermal well model size(Unit: m);

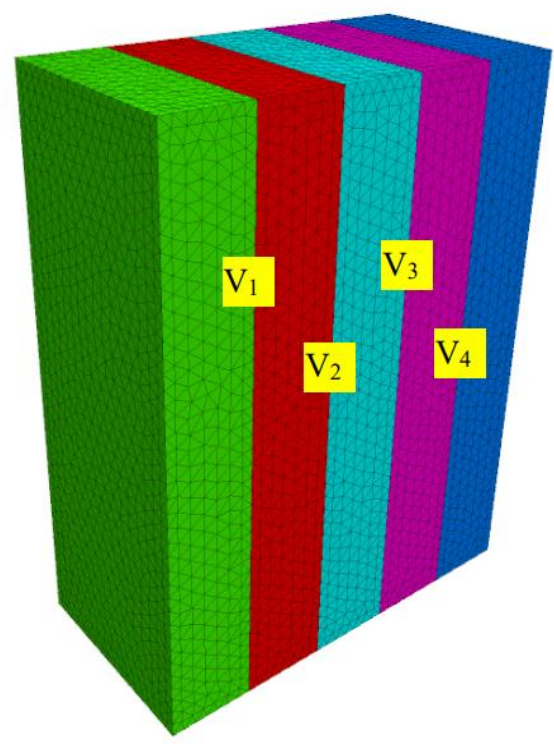

(b) Model mesh generation.

Fig. 2 Geothermal well model size and mesh generation

\section{Parameters and content}

Under conventional conditions, the thermophysical parameters of rock and water were shown in Table 1 , in which the heat convection coefficient of rock and water was $30 \mathrm{~W} /\left(\mathrm{m}^{2} \cdot{ }^{\circ} \mathrm{C}\right)$ 。

Table 1 Thermo-physical parameters of the rock and water

\begin{tabular}{cccc}
\hline material & $\begin{array}{c}\text { density } \\
/\left(\mathrm{kg} / \mathrm{m}^{3}\right)\end{array}$ & $\begin{array}{c}\text { Specific heat } \\
/\left(\mathrm{J} /\left(\mathrm{g} \cdot{ }^{\circ} \mathrm{C}\right)\right)\end{array}$ & $\begin{array}{c}\text { Coefficient of thermal } \\
\text { conductivity } \\
/\left(\mathrm{W} /\left(\mathrm{m} \cdot{ }^{\circ} \mathrm{C}\right)\right)\end{array}$ \\
\hline rock & 2700 & 0.8 & 2.3 \\
\hline water & 1000 & 4.2 & 0.6 \\
\hline
\end{tabular}

The calculation conditions of the model were shown in Fig. 3. The calculation was carried out according to the principle of setting the same opening of geothermal wells, ensuring the same flow rate of injection wells and production wells, and the same water flow velocity of injection wells and production wells. The calculation contents of the model were shown in Table 2. The inlet water temperature of production well was $90^{\circ} \mathrm{C}$, the opening of fracture (production well) was 2.5 $\mathrm{mm}$, and fractures $\mathrm{V}_{1}$ and $\mathrm{V}_{4}$ were set to inject water, $\mathrm{V}_{2}$ and $\mathrm{V}_{3}$ were set to outlet water, and the water flow speed was $2 \mathrm{~mm} / \mathrm{s}$; Set the fracture $V_{1}$ and $V_{4}$ to outlet water, $V_{2}$ and $V_{3}$ to inject water, and the water flow speed was $2 \mathrm{~mm} / \mathrm{s}$; Set fracture $V_{1}$ and $V_{2}$ to inject water, $V_{3}$ and $V_{4}$ to outlet water, and the water flow speed was $2 \mathrm{~mm} / \mathrm{s}$; The fractures $V_{1}$ and $V_{3}$ were injected with water and $V_{2}$ and $V_{4}$ with water flow velocity of $2 \mathrm{~mm} / \mathrm{s}$. under these four working conditions, the influence of different water injection and water flow on the heat transfer temperature of rock mass was calculated and analyzed. The data obtained under each working condition were processed by post-processing software into rock mass temperature field and water temperature-time curve at the outlet of production well for comparative analysis. 


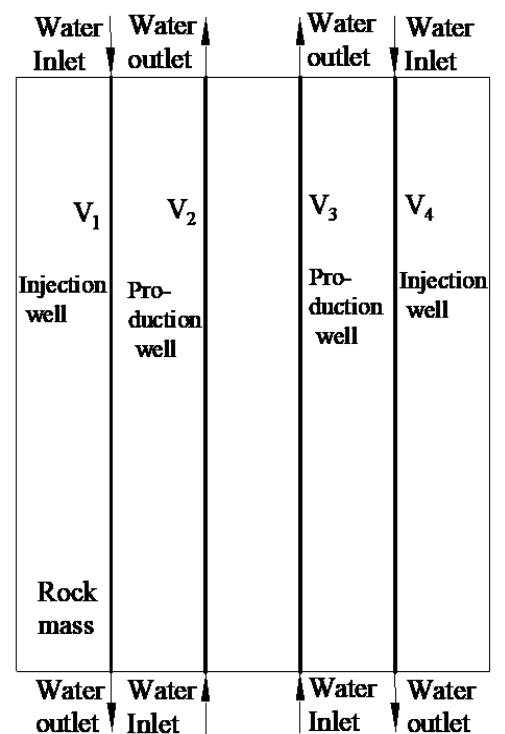

(a) Working condition 1

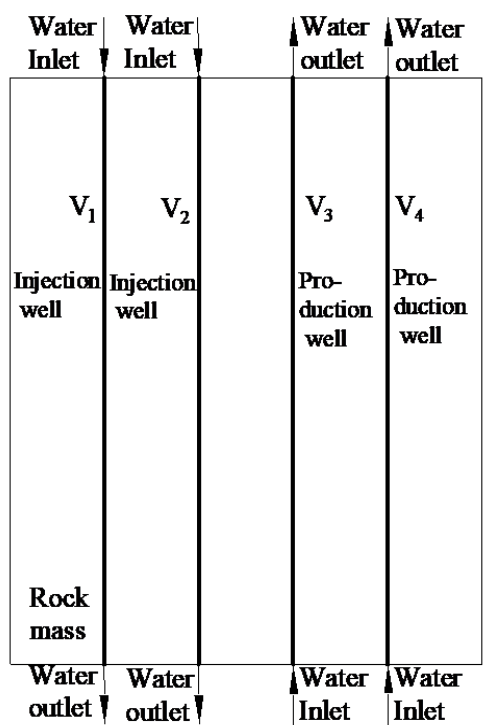

(c) Working condition 3

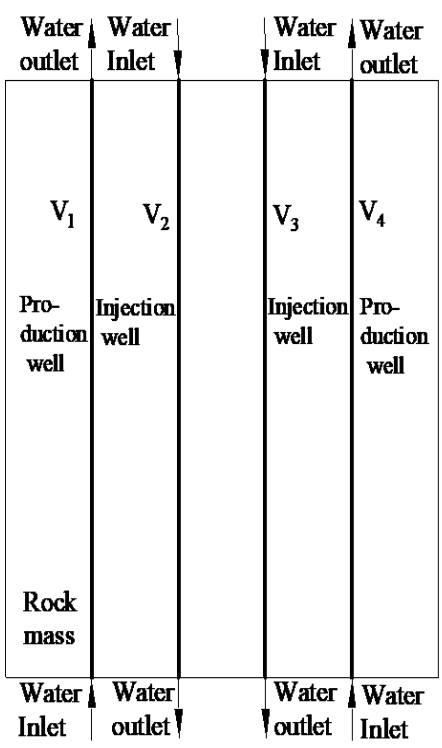

(b) Working condition 2

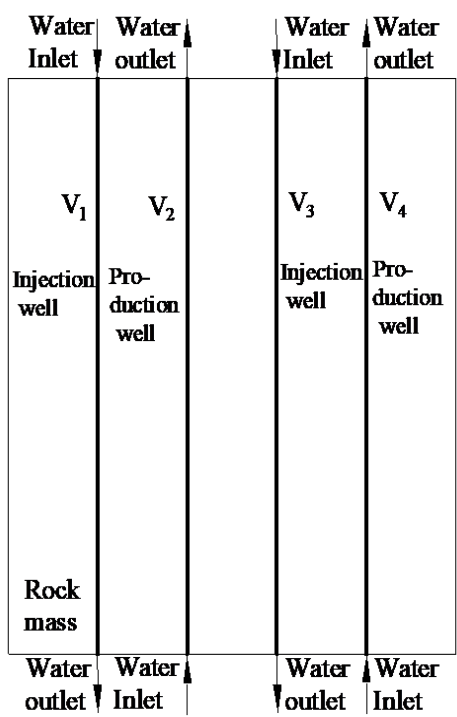

(d) Working condition 4

Fig. 3 Model calculation conditions 
Table 2 Numerical simulation conditions

\begin{tabular}{|c|c|c|c|c|}
\hline $\begin{array}{l}\text { Calculation } \\
\text { content }\end{array}$ & Water injection mode & $\begin{array}{c}\text { Water } \\
\text { velocity } /(\mathrm{mm} / \mathrm{s})\end{array}$ & $\begin{array}{c}\text { Inlet water } \\
\text { temperature of } \\
\text { production well } \\
\qquad /\left({ }^{\circ} \mathrm{C}\right)\end{array}$ & $\begin{array}{l}\text { Fracture (geothermal } \\
\text { well) opening } /(\mathrm{mm})\end{array}$ \\
\hline 1 & $\begin{array}{c}\mathrm{V}_{1}, \mathrm{~V}_{4} \text { water injection, } \mathrm{V}_{2} \\
\mathrm{~V}_{3} \text { water outlet }\end{array}$ & \multirow{4}{*}{2} & \multirow{4}{*}{90} & \multirow{4}{*}{2.5} \\
\hline 2 & $\begin{array}{c}\mathrm{V}_{1}, \mathrm{~V}_{4} \text { water outlet, } \mathrm{V}_{2}, \mathrm{~V}_{3} \\
\text { water injection }\end{array}$ & & & \\
\hline 3 & $\begin{array}{c}V_{1} 、 V_{2} \text { water injection, } V_{3} \text {, } \\
V_{4} \text { water outlet }\end{array}$ & & & \\
\hline 4 & $\begin{array}{c}V_{1} 、 V_{3} \text { water injection, } V_{2} \text { 、 } \\
V_{4} \text { water outlet }\end{array}$ & & & \\
\hline
\end{tabular}

\section{Results and analysis}

Influence of different injection wells and outlet wells on temperature field of rock mass

Under four working conditions, when the model reached a steady state, the temperature field of rock mass was shown in Fig. 4.

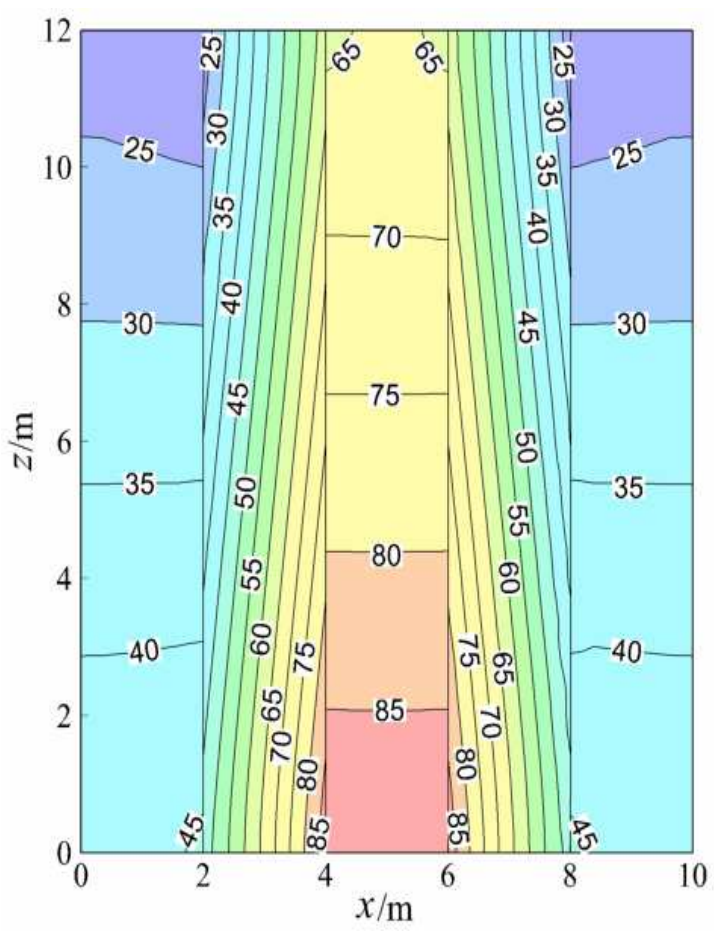

(a) Working condition 1

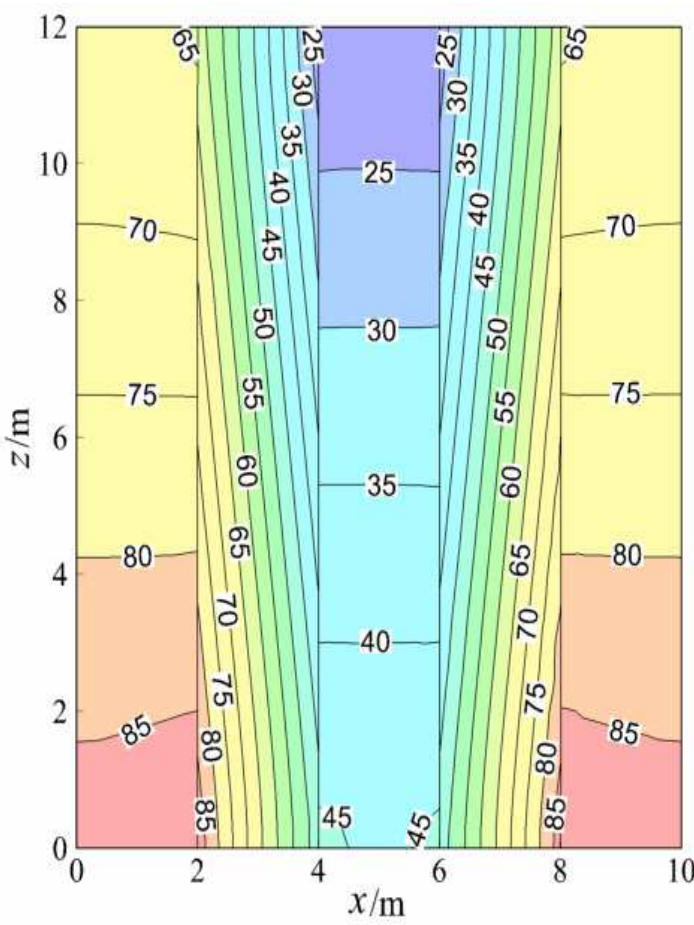

(b) Working condition 2 


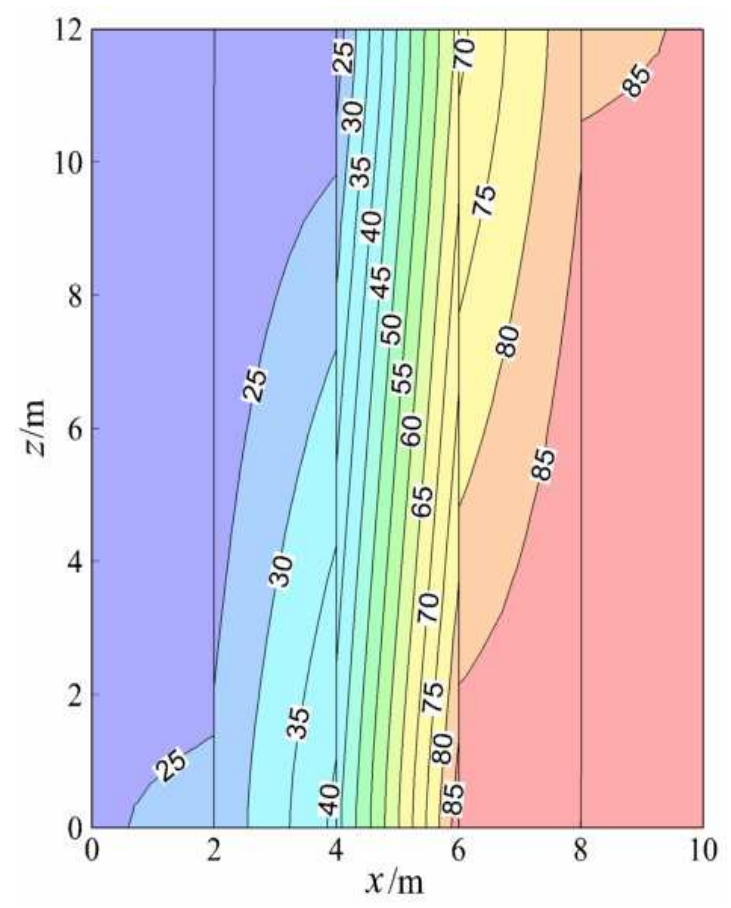

(c) Working condition 3

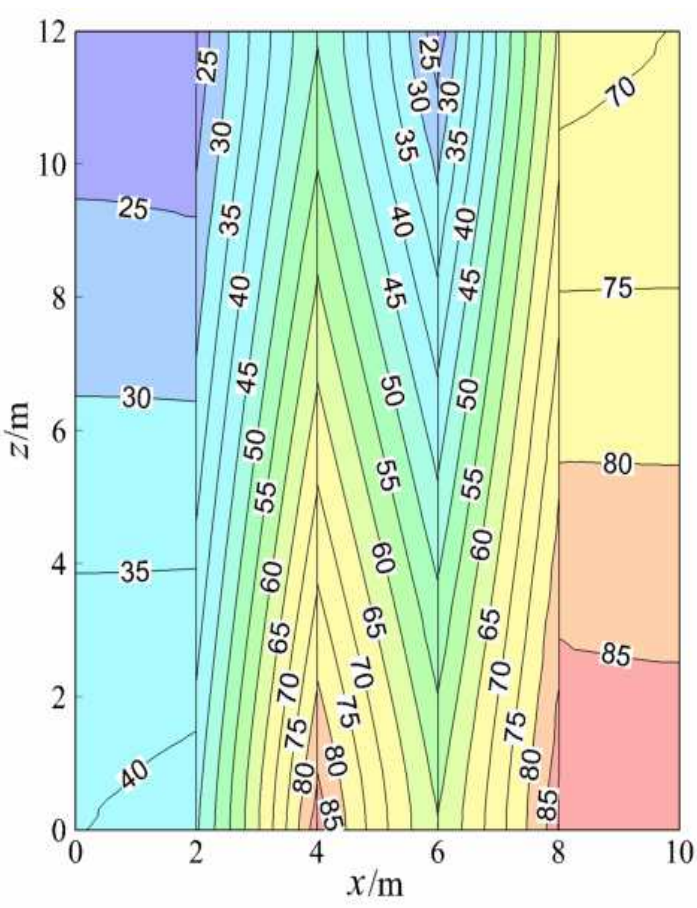

(d) Working condition 4

Fig. 4 temperature field of rock mass

According to Fig. 4 (a) and Fig. 4 (b), in the initial state, low temperature water $\left(20^{\circ} \mathrm{C}\right)$ was injected into the ground along with injection wells $\mathrm{V}_{1}\left(\mathrm{~V}_{2}\right)$ and $\mathrm{V}_{4}\left(\mathrm{~V}_{3}\right)$, while high temperature water $\left(90^{\circ} \mathrm{C}\right)$ was pumped out from production wells $\mathrm{V}_{2}\left(\mathrm{~V}_{1}\right)$ and $\mathrm{V}_{3}\left(\mathrm{~V}_{4}\right)$. When the high temperature water of production well $\mathrm{V}_{2}\left(\mathrm{~V}_{1}\right)$ and $\mathrm{V}_{3}\left(\mathrm{~V}_{4}\right)$ entered the production well, it has convected heat transfer with the rock mass on both sides of production well (initial $20{ }^{\circ} \mathrm{C}$ ), that is, the heat absorption temperature of the rock mass on both sides of production well gradually increased, and the heat release temperature of the water flow of production well gradually decreased. With the temperature of the rock mass on both sides of the production well increasing, When the low temperature water flow of injection wells $\mathrm{V}_{1}\left(\mathrm{~V}_{2}\right)$ and $\mathrm{V}_{4}\left(\mathrm{~V}_{3}\right)$ passed through the rock mass with elevated temperature on one side, heat convection occurs between them. The three processes of water flow heat release of production wells (heat convection between water flow of production well and its rock mass wall), the production wells water absorbed heat by contacting the rock mass wall (respective heat conduction of production well water and rock mass wall) and water flow heat absorption of injection wells (heat convection between water flow of injection well and its rock mass wall) were accompanied by water injection and water pump until the model reached a steady state. At this time, the total amount of heat provided by the inlet water of the production wells was equal to the heat absorbed by the rock mass at its side wall and the heat absorbed by the water flow of the injection well, and they reached a dynamic equilibrium. After the injection wells and production wells under two working conditions were switched, their temperature gradients were similar and symmetrical. The rock mass temperature gradients on both sides of injection wells (production wells) were about $1.67^{\circ} \mathrm{C} / \mathrm{m}$ and $4.93^{\circ} \mathrm{C} / \mathrm{m}$.

Comparison between Fig. 4(a) and Fig. 4(c) showed that after the middle production well and edge injection well in Fig. 4(a) were changed to the left adjacent production well and the right adjacent injection well in Fig. 4 (c), the temperature field of rock mass of both sides of the edge formed a central symmetry, and the temperature gradient from the middle to both sides of the rock 
mass becomed smaller and smaller, showed that the water temperature at the outlet of injection well $\mathrm{V}_{1}$ decreased significantly and that at the outlet of production well $\mathrm{V}_{4}$ increased significantly, the water temperature at the outlet of injection well $V_{2}$ decreased slightly, while that at the outlet of production well $\mathrm{V}_{3}$ increased slightly. This is due to the thermal superposition effect of the adjacent injection well and the production well through the rock mass respectively, which leaded to the higher temperature of the production well. Comparison between Fig. 4(a) and Fig. 4(d) showed that from the middle production well in Fig. 4 (a), the edge injection well was changed to the interval between injection well and production well in Fig. 4 (d). The temperature field of rock mass of both sides of the edge formed a central symmetry, and the temperature gradient from the middle to both sides of the rock mass becomed smaller and smaller, showed that the water temperature at the outlet of injection well $\mathrm{V}_{1}$ decreased slightly and that at the outlet of injection well $\mathrm{V}_{3}$ increased significantly, the water temperature at the outlet of production well $\mathrm{V}_{2}$ decreased significantly, while the water temperature at the outlet of production well $\mathrm{V}_{4}$ changed little, and the temperature gradient mainly showed a large difference between X (4-6m). This was because in Fig. 4 (a), the heat superposition effect occured in the middle production well through the rock mass between them, forming a temperature gradient from the bottom to the top, while in Fig. 4(d), there was no heat superposition effect between the water injection wells and the production wells, but the heat convection between injection wells and the production wells was dominant, and the temperature gradient was mainly formed from left to right in a steady state. Comparing Fig. 4(c) with Fig. 4(d), it can be seen that water injection wells $V_{2}$ and $V_{3}$ in Fig. 4(c) were changed into production wells $V_{2}$ and $V_{3}$ in Fig. 4(d), that is, adjacent injection wells and adjacent production wells were changed into spaced injection wells and production wells. in Fig. 4(c), the heat superposition effect between adjacent production wells was dominant, which made the water temperature of production wells outlet increased greatly, while in Fig. 4(d), the heat convection was dominant in the injection wells and production wells, which made the water temperature at the outlet of production well decreased greatly.

\section{Temperature field analysis of water injection well and water outlet well}

Under four working conditions, when the model reached a steady state, the temperature fields of injection wells and water outlet wells were shown in Fig. 5, 6, 7 and 8. 


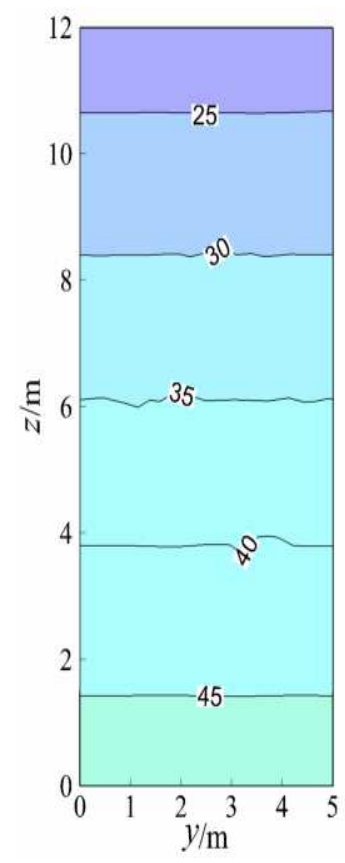

(1) water injection well $\mathrm{V}_{1}$

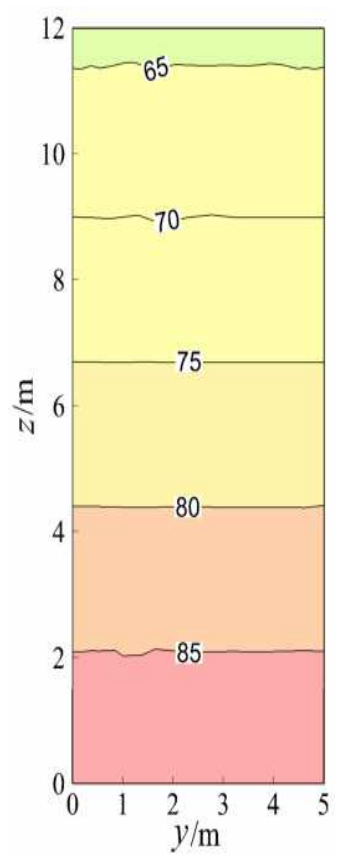

(2) production well $\mathrm{V}_{2}$

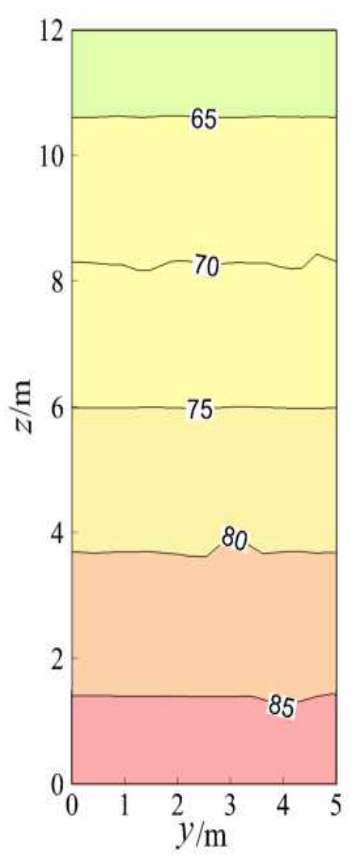

(3) production well $\mathrm{V}_{3}$

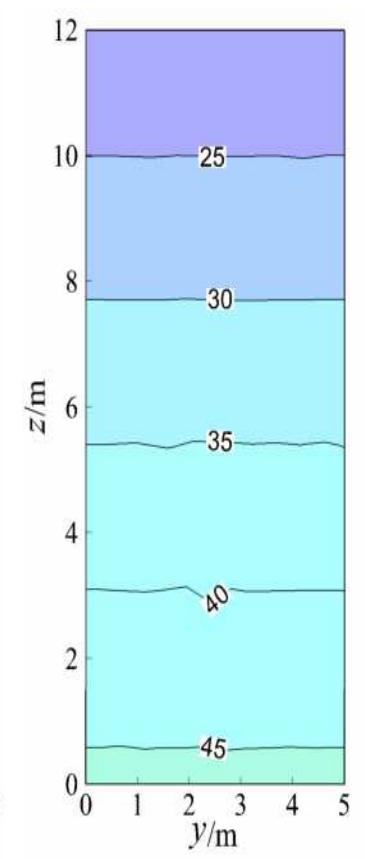

(4) water injection well $\mathrm{V}_{4}$

Fig. 5 Temperature field of geothermal well plane (working condition 1)
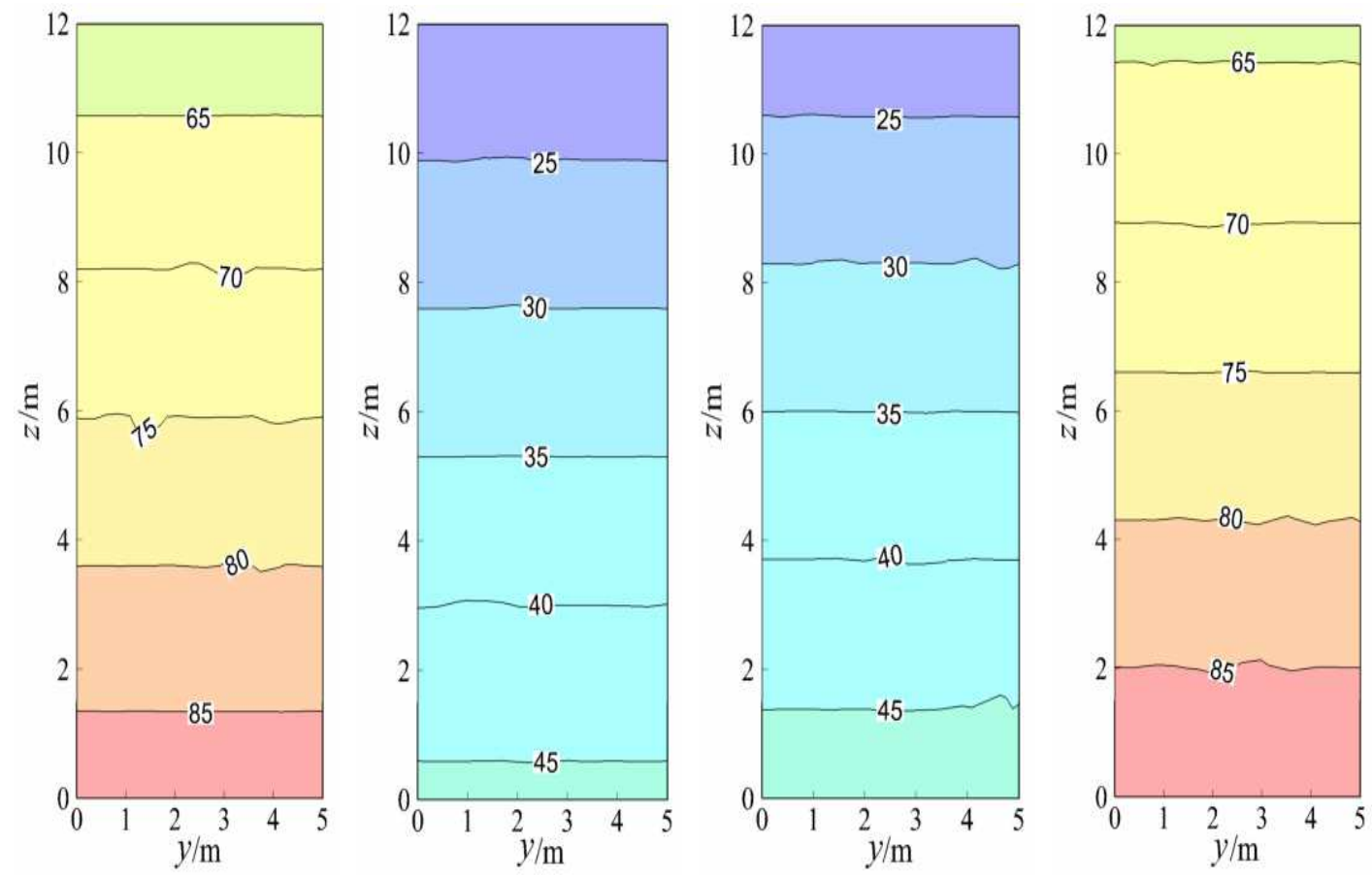

$\begin{array}{ll}\text { (1) production well } \mathrm{V}_{1} & \text { (2) water injection well } \mathrm{V}_{2}\end{array}$

(3) water injection well $\mathrm{V}_{3}$

(4) production well $\mathrm{V}_{4}$

Fig. 6 Temperature field of geothermal well plane (working condition 2) 


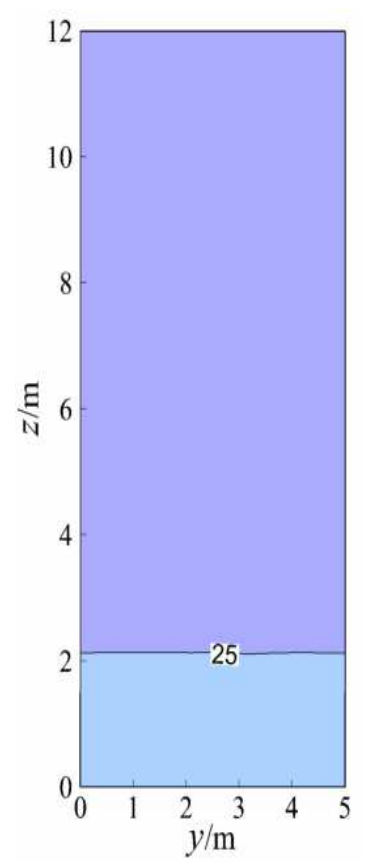

(1) water injection well $\mathrm{V}_{1}$

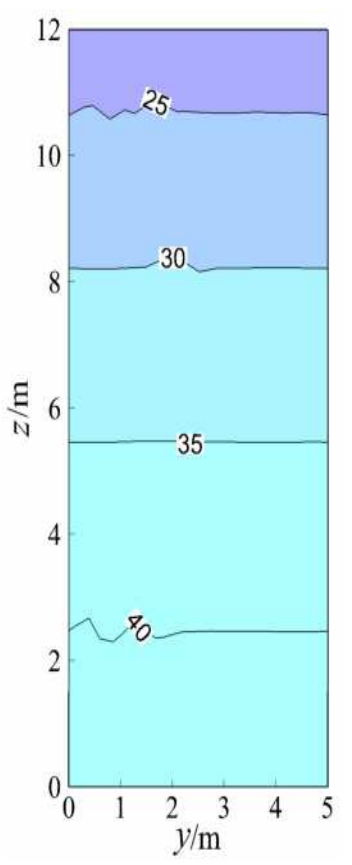

(2) water injection well $\mathrm{V}_{2}$

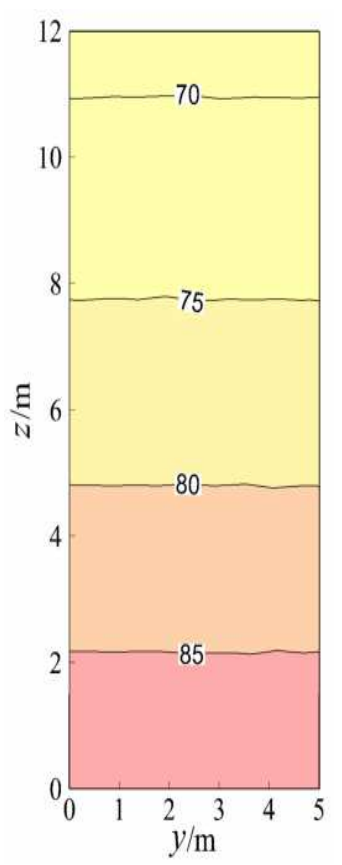

(3) production well $\mathrm{V}_{3}$

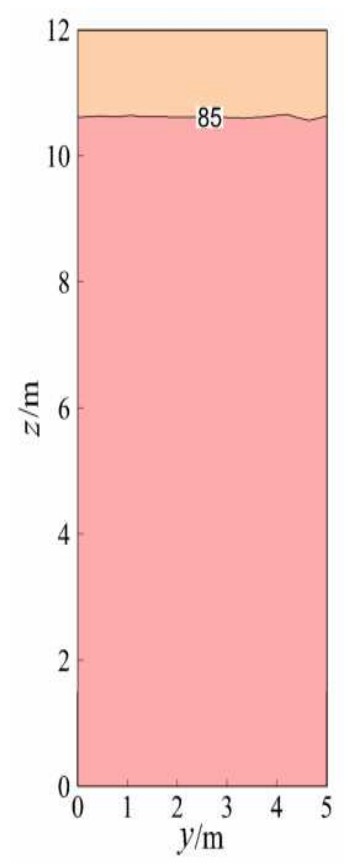

(4) production well $\mathrm{V}_{4}$

Fig. 7 Temperature field of geothermal well plane (working condition 3)

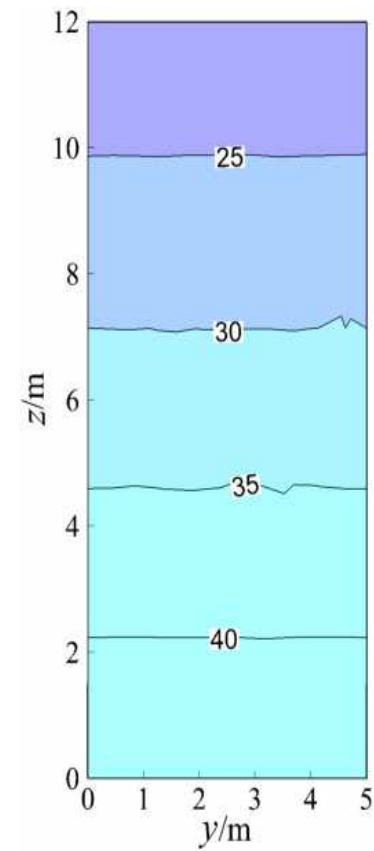

(1) water injection well $\mathrm{V}_{1}$

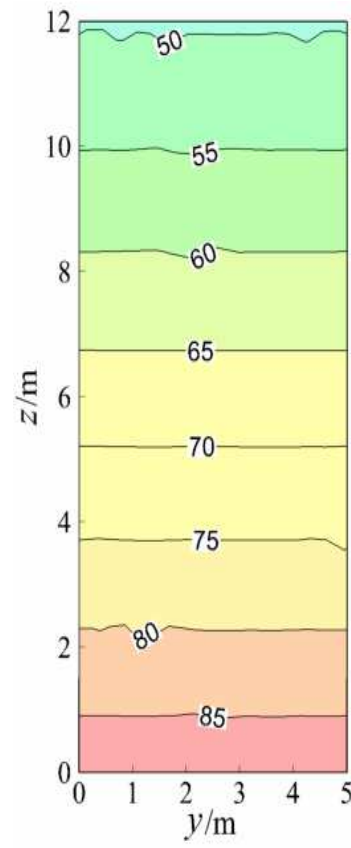

(2) production well $\mathrm{V}_{2}$

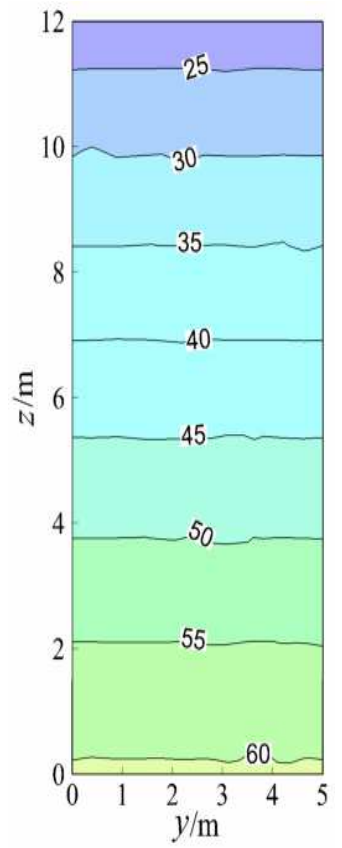

(3) water injection well $\mathrm{V}_{3}$

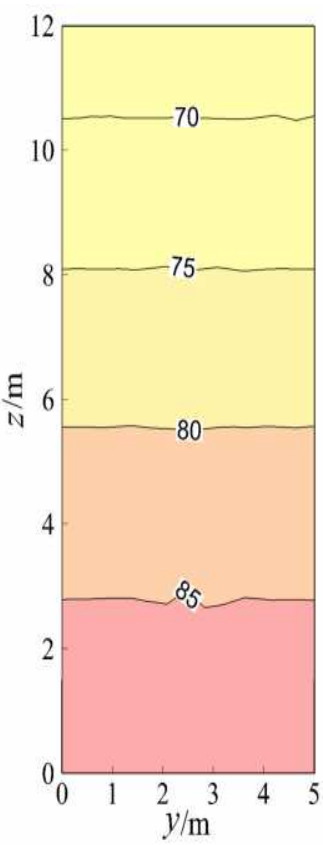

(4) production well $\mathrm{V}_{4}$

Fig. 8 Temperature field of geothermal well plane (working condition 4)

As shown in Fig. 5, when the model reached a steady state, the production well $\mathrm{V}_{1}, \mathrm{~V}_{4}$ and injection well $\mathrm{V}_{2}$ and $\mathrm{V}_{3}$ were symmetrical, and the theoretical isotherms should be the same. The slight difference between the temperature fields of production well and injection well was due to the random distribution of the model calculation grid, which had certain errors. The temperature gradient of the overall injection well and the production well was similar, the temperature gradients of production wells $\mathrm{V}_{1}$ and $\mathrm{V}_{4}$ and injection wells $\mathrm{V}_{2}$ and $\mathrm{V}_{3}$ were almost the same (about $2.13^{\circ} \mathrm{C} / \mathrm{m}$ ). As can be seen from Fig. 5 and Fig. 6, after the switch between production well and water injection well, the temperature gradients of the production well $\mathrm{V}_{1}$ and $\mathrm{V}_{4}$ and the 
injection well $\mathrm{V}_{2}$ and $\mathrm{V}_{3}$ were almost the same (about $2.15^{\circ} \mathrm{C} / \mathrm{m}$ ). The temperature gradients of the production well and injection well under two working conditions were almost the same in numerical terms, but the difference was that the temperature gradients were in opposite directions. It was shown in Fig. 5 and Fig.7 that after the changed from the middle production well and edge injection well in Fig. 5 to the injection well on the left and the production well on the right, the temperature gradient of $\mathrm{V}_{1}$ and $\mathrm{V}_{2}$ of injection well was about $0.51^{\circ} \mathrm{C} / \mathrm{m}$ and $1.85^{\circ} \mathrm{C} / \mathrm{m}$ respectively. The temperature gradient of production well $\mathrm{V}_{3}$ and $\mathrm{V}_{4}$ was about $1.69^{\circ} \mathrm{C} / \mathrm{m}$ and $0.47^{\circ} \mathrm{C}$ $/ \mathrm{m}$ respectively, and the temperature gradient decreased. The reason was that the boundary conditions of injection wells and production wells have be changed. Comparison between Fig. 5 and Fig. 8 showed that the middle production well and marginal injection well in Fig. 5 were changed into interval injection wells and production wells in Fig. 8. In fig. 8, the temperature gradients of the injection wells $\mathrm{V}_{1}$ and $\mathrm{V}_{3}$ were about $1.95^{\circ} \mathrm{C} / \mathrm{m}$ and $3.13^{\circ} \mathrm{C} / \mathrm{m}$ respectively, and that of production wells $\mathrm{V}_{2}$ and $\mathrm{V}_{4}$ were about $3.18^{\circ} \mathrm{C} / \mathrm{m}$ and $1.97^{\circ} \mathrm{C} / \mathrm{m}$ respectively. The temperature gradients of water injection wells $\mathrm{V}_{1}$ and $\mathrm{V}_{4}, \mathrm{~V}_{3}$ and $\mathrm{V}_{2}$ were similar. This is due to the similar boundary conditions between interval injection wells and production wells. According to the comparison between Fig.7 and Fig.8, the injection wells $V_{2}$ and $V_{3}$ in Fig. 7 were changed into the production wells $V_{2}$ and $V_{3}$ in Fig. 8. That is, adjacent injection wells and adjacent production wells were changed into spaced injection wells and production wells, the temperature gradient of water flow in injection wells and production wells in Fig. 7 was much smaller than that in Fig. 8. This is because heat convection between spaced injection wells and production wells was dominant and the water flow and heat transfer speed was faster under the premise of constant thermal resistance between rock mass and water flow contact surface.

\section{Water temperature-time analysis of geothermal well outlet}

The temperature-time curve of geothermal well outlet was shown in Fig. 9 under four conditions.

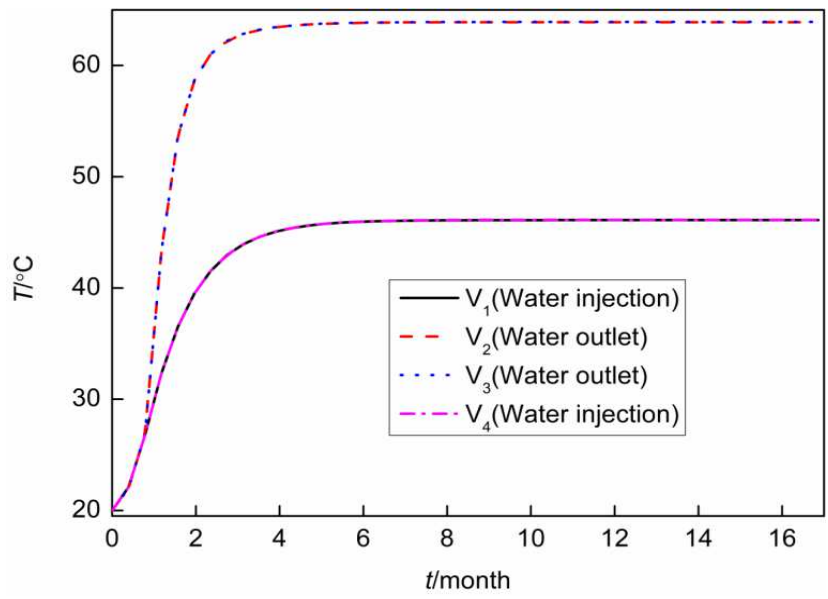

(a) Working condition 1 


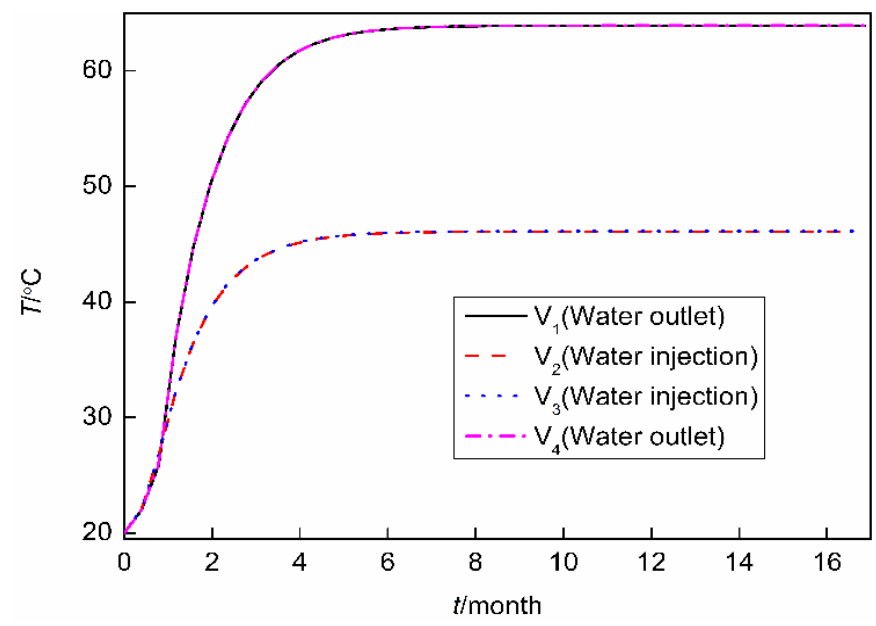

(b) Working condition 2

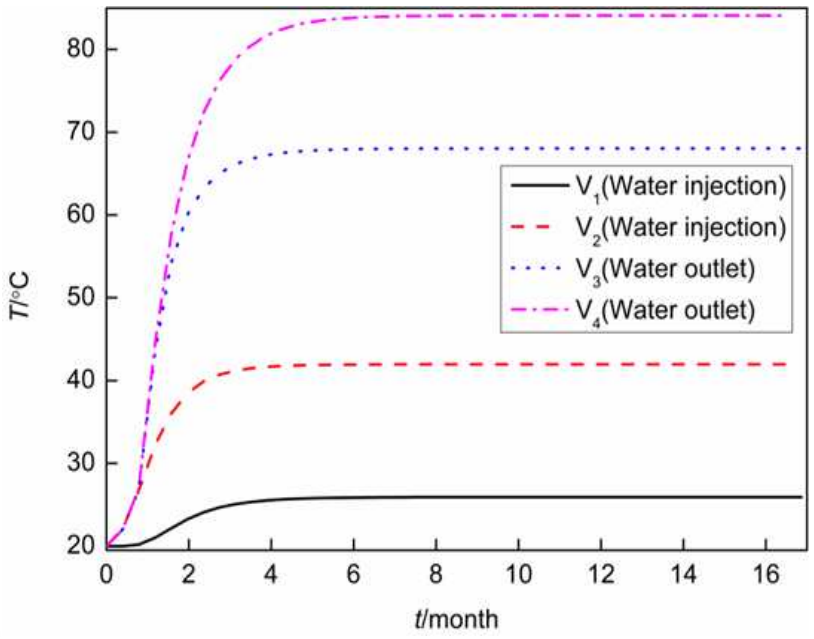

(c) Working condition 3

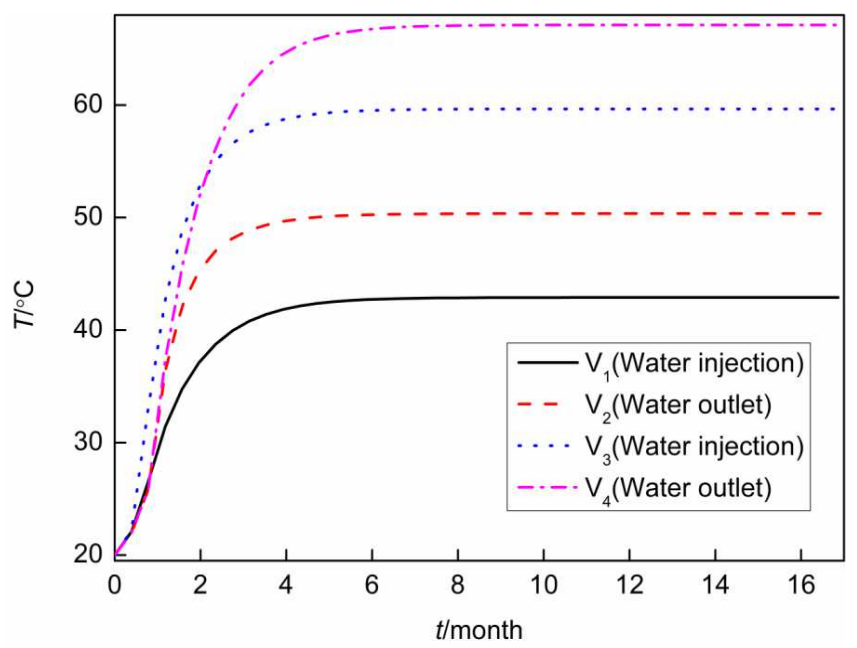

(d) Working condition 4

Fig. 9 Temperature-time curve of geothermal well outlet

As can be seen from Fig. 9 (a), under the condition that the middle part was production well and the edge was injection well, due to the symmetry of the model, the water temperature-time curve of the production well $\mathrm{V}_{1}$ and $\mathrm{V}_{4}$, the injection well $\mathrm{V}_{2}$ and $\mathrm{V}_{3}$ coincided from the beginning to the end. It took about 7 months for the model to reach a steady state. At this time, the water 
temperature at the outlet of the production well reached $63.9{ }^{\circ} \mathrm{C}$, the water temperature at the outlet of the injection well reached $46.1{ }^{\circ} \mathrm{C}$, and the water temperature of the production wells was $38.61 \%$ higher than that of injection wells. According to the comparison in Fig. 9 (a) and (b), it took about 7 months for the model in working condition 2 to reach a steady state after the switch between injection wells and production wells. At this time, the water temperature at the outlet of the production well $\mathrm{V}_{1}, \mathrm{~V}_{4}$ and the injection well $\mathrm{V}_{2}$ and $\mathrm{V}_{3}$ was basically the same as that at the production wells $\mathrm{V}_{2}, \mathrm{~V}_{3}$ and injection wells $\mathrm{V}_{1}$ and $\mathrm{V}_{4}$ in working condition 1 . As can be seen from Fig. 9 (c), it took about 6 months for the model to reach steady state. At this time, the water temperature at the outlet of production wells $\mathrm{V}_{3}$ and $\mathrm{V}_{4}$ reached $68.0^{\circ} \mathrm{C}$ and $84.0^{\circ} \mathrm{C}$ respectively, and the water temperature at the outlet of the injection wells $\mathrm{V}_{1}$ and $\mathrm{V}_{2}$ reached $41.9^{\circ} \mathrm{C}$ and $25.9^{\circ} \mathrm{C}$ respectively. The reason was that the thermal superposition effect of the water flow of the adjacent production well was dominant. The heat absorption capacity of rock mass boundary on the right side of production well $\mathrm{V}_{4}$ (outside of the model was the adiabatic boundary) was less than that on the left side of the production well $\mathrm{V}_{3}$ ( heat absorption capacity of the injection well $\mathrm{V}_{2}$ ). Similarly, although some heat superposition effect would occur in the water flow of adjacent production Wells $\mathrm{V}_{1}$ and $\mathrm{V}_{2}$, However, the heat absorption capacity of rock mass boundary on the right side of the injection well $\mathrm{V}_{2}$ (heat release from the production well $\mathrm{V}_{3}$ ) was greater than that on the left side of the injection well $\mathrm{V}_{1}$ (outside the model was the adiabatic boundary). According to the comparison between Fig. 9 (a) and Fig. 9 (c), the water temperature at the outlet of the production well and the injection well changed greatly when the central production well and the edge injection well were changed from Fig. 9 (a) to Fig. 9 (c), when the injection well was adjacent to the injection well on the left and adjacent to the production well on the right. The water temperature at the outlet of the production well in working condition 3 was $4.1^{\circ} \mathrm{C}\left(68.0^{\circ} \mathrm{C}-63.9^{\circ} \mathrm{C}\right)$ and $20.1^{\circ} \mathrm{C}\left(84.0^{\circ} \mathrm{C}-63.9^{\circ} \mathrm{C}\right)$ higher than that in working condition 1 , respectively. The average water temperature at the outlet of the production well in working condition 3 was about $12.1^{\circ} \mathrm{C}$ $\left(76.0^{\circ} \mathrm{C}-63.9^{\circ} \mathrm{C}\right)$ higher than that in working condition 1 . As can be seen from Fig.9 (d), it took about 10 months for the model to reach steady state. At this time, the water temperature at the outlets of the production well $\mathrm{V}_{4}$ and $\mathrm{V}_{2}$ reached $67.1^{\circ} \mathrm{C}$ and $50.4^{\circ} \mathrm{C}$, while the water temperature at the outlets of the injection well $\mathrm{V}_{3}$ and $\mathrm{V}_{1}$ reached $59.7^{\circ} \mathrm{C}$ and $42.9^{\circ} \mathrm{C}$. Therefore, it can be seen that the water temperature of injection wells outlet $\left(59.7^{\circ} \mathrm{C}\right)$ was higher than that of production wells $\left(50.4^{\circ} \mathrm{C}\right)$ in working condition 4 . This is because after the separation between injection well and production well, one side of the boundary of the water flow on both sides of the production well $\mathrm{V}_{4}$ was the adiabatic boundary of the rock mass, and the other side was the heat absorption boundary of the water flow on the injection well $\mathrm{V}_{3}$. Both sides of the water flow on the production well $\mathrm{V}_{2}$ were the injection wells $\mathrm{V}_{3}$ and $\mathrm{V}_{1}$ ( outer side of production well $\mathrm{V}_{2}$ was the endothermic boundary of water flow), so the water temperature at the outlet of the production well $\mathrm{V}_{4}$ was higher than that of the production well $\mathrm{V}_{2}$. Both sides of the injection well $\mathrm{V}_{3}$ were heat release boundaries of production wells $\mathrm{V}_{4}$ and $\mathrm{V}_{2}$. Obviously, the high temperature water flow of two production wells provided the boundary conditions for both sides of the injection well $V_{3}$ to absorb more heat. Water flow of the injection well $\mathrm{V}_{1}$ absorbed heat of production well $\mathrm{V}_{2}$ only through heat convection, so its temperature was the lowest. It can be seen from the comparison of Fig. 9(a) and Fig. 9(d) that water temperature of production wells and injection wells outlet has changed greatly under two working conditions, and water temperature of production wells outlet in working condition 4 was $3.2^{\circ} \mathrm{C}\left(67.1^{\circ} \mathrm{C}-63.9^{\circ} \mathrm{C}\right)$ and $-13.5^{\circ} \mathrm{C}\left(50.4^{\circ} \mathrm{C}-63.9^{\circ} \mathrm{C}\right)$ higher than that in 
working condition 1 , and the average water temperature at the outlet of production well in working condition 4 was about $8.35^{\circ} \mathrm{C}\left(67.1^{\circ} \mathrm{C}-58.75^{\circ} \mathrm{C}\right)$ lower than that in working condition 1 , so working conditions 1 and 2 were superior to working condition 4.According to the comprehensive comparison of Fig. 9(a), 9(b), 9(c) and 9(d), it can be seen that according to the water temperature at the outlet of production well, the optimal order of the model was working condition $3>$ working condition 1 = working condition $2>$ working condition 4 . In addition, the time required for model of working condition 3 to reach steady state was the shortest, while that of model of working condition 4 was the longest.

\section{conclusion}

In this paper, a three-dimensional numerical model was established to optimize mechanism of thermal recovery efficiency under different geothermal well layout conditions. Set fractures $V_{1}$ and $V_{4}$ are set to inject water, $V_{2}$ and $V_{3}$ are set to outlet water; Set the fracture $V_{1}$ and $V_{4}$ to discharge water, $V_{2}$ and $V_{3}$ to inject water; Set fracture $V_{1}$ and $V_{2}$ to inject water, $V_{3}$ and $V_{4}$ to outlet water; The fractures $V_{1}$ and $V_{3}$ are injected with water and $V_{2}$ and $V_{4}$. under these four working conditions, the influence of different water injection and water flow on the heat transfer temperature of rock mass flow is calculated and analyzed by 3DEC program. This program is specially used in numerical analysis of jointed rock mass, and it has high accuracy in simulating water-heat coupling of fractured rock mass. Geothermal resources is exploited in deep rock and soil, so it is very suitable for this process simulation. The calculations reveal:

(1) After the model water injection wells are switched with the production wells, the temperature gradients of rock mass, production wells and injection wells are almost the same in numerical value and opposite in direction.

(2) Production wells are set on the left side and injection wells are set on the right side of the model, and the injection wells and production wells are set at intervals; The temperature field of the rock mass on both sides of the edge forms a central symmetry; The temperature gradient of rock mass from the middle to the edge is smaller and smaller, which indicates that the heat transfer speed of rock mass from the middle to the edge is slower and slower. Because the thermal superposition of adjacent injection wells and production wells through the rock mass between them is dominant, the water temperature at the outlet of production wells is the highest; In the interval injection well and production well, the convection heat transfer between water flow and rock is dominant, which makes the outlet water temperature of production well drop.

(3) According to the water temperature at the outlet of production well, the optimal order of the model is working condition $3>$ working condition $1=$ working condition $2>$ working condition 4 , and the time to reach a steady state is the shortest in working condition 3 and the longest in working condition 4 . The research results can provide important theoretical and practical reference value for optimizing the layout of geothermal wells in efficient geothermal exploitation.

\section{Availability of data and materials}

The data and materials are authentic and reliable.

\section{Acknowledgements}

Thanks to the Shandong Provincial Lunan Geology and Exploration Institute. Support was provided by School of Architecture and Civil Engineering, Yan' an University, Yan' an 716000. Funding was provided by the General Project of Yan 'an University's scientific research plan (YDY2020-35) and Key Project of Shandong Lunan Geological Engineering Investigation 
Institute Open Fund (LNYQ2021-Z06).

\section{Funding}

General Project of Yan 'an University's scientific research plan (YDY2020-35). Key Project of

Shandong Lunan Geological Engineering Investigation Institute Open Fund (LNYQ2021-Z06).

\section{Author information}

\section{Affiliations}

School of Architecture and Civil Engineering, Yan' an University, Yan' an 716000, China Jun-yi Gao

Shandong Provincial Lunan Geology and Exploration Institute, Jining 272100, China Jun-yi Gao

\section{Contributions}

GJY completed literature collection, manuscript conception, model construction and calculation, and finally carried out data processing and analysis, and wrote the final manuscript.

Corresponding author

Correspondence to Jun-yi Gao.

\section{Ethics declarations}

\section{Competing interests}

The author declare no competing financial interests.

\section{References}

Angelotti A, Alberti L, Licata I L, et al. Energy performance and thermal impact of a borehole heat exchanger in a sandy aquifer:influnce of the groundwater velocity. Energy Conversion and Management.2014;(77):700-708,

Dehkordi, S E, Schincariol, R A. Effect of thermal-hydrogeological and borehole heat exchanger properties on performance and impact of vertical closed-loop geothermal heat pump systems. Hydrogeol J.2014;(22):189-203.

Dou H-P, Chen X-H, Zhu P, et al. A model of temperature loss in the wellbore of geothermal exploitation for heating and its application. Geology and Exploration.2019; 55(05): 12761286 (in Chinese).

Gao J-Y. Study on mechanism of the influence of geothermal temperature and production well depth on water flow and heat transfer temperature in rock mass. Progress in Geophysics.2020; 35(05):1659-1664 (in Chinese).

Gao J-Y. Study on geothermal well spacing based on water flow and heat transfer rock mass . Progress in Geophysics. 2020;35 (06):2058-2063 (in Chinese).

Gao Q, Ghassemi A. Three-Dimensional Thermo-Poroelastic Modeling and Analysis of Flow. Geothermal System. Rock Mech Rock Eng, 2020， 53, 1565-1586.

Jin M-G, Tan Q-J, Li X-W. Optimum location of pumping and inj ection wells of groundwater heat exchange system using numerical modeling of water and heat transport. Bulletin of Geological Science and Technology.2012;31(05):128-135.

Joël M. Zinsalo, Louis Lamarche, Jasmin Raymond.Sustainable electricity generation from an Enhanced Geothermal System considering reservoir heterogeneity and water losses with a discrete fractures model. Applied Thermal Engineering.2021;192.

Li W-W, Rao S, Tang X-Y, et al. Borehole temperature logging and temperature field in the xiongxian geothermal field, Hebei Province.Chinese Journal of Geology.2014;49(3): 850 
-863(in Chinese).

Li F-Y, Xu T-F, Feng G-H, et al. Simulation for water-heat coupling process of single well ground source heat pump systems implemented by T2well. Acta Energiae Solaris Sinica.2020;41(04): 278 -286(in Chinese).

Loret B. Enhanced Geothermal Systems (EGS): Hydraulic Fracturing in a Thermo-Poroelastic Framework. In: Fluid Injection in Deformable Geological Formations. Springer, Cham, 2019.

Yu L-K, Wu X-T, Hassan N M S, et al., Modified zipper fracturing in enhanced geothermal system reservoir and heat extraction optimization via orthogonal design.Renewable Energy.2020;161:373-385(in Chinese).

Ma Z-Y, Zhai M-J, Xu Y, et al. Reasonable well spacing and layout optimization of shallow source heat pump using sand trough simulation:a case study in Feuglinjiuxi. Journal of Water Resources and Water Engineering.2018;29(04):143-149(in Chinese).

Ma J-C, Shao G, Wang Y, et al. Influence of the distribution of pumping and injection wells on heat transfer characteristic of borehole heat exchangers. Journal of Basic Science and Engineering.2019;(05):1158-1171(in Chinese).

Ma J-C, Shao G, Xie Y-C, et al. Influence of the distribution of pumping and injection wells on heat transfer characteristic of borehole heat exchangers. Acta Energiae Solaris Sinica. 2020; 41 (03):109-118(in Chinese).

Rees S J, He M M. A three-dimensional numerical model of borehole heat exchanger heat transfer and fluid flow. Geothermics.2013;46( 10): 1-13.

Shen X-S. Analysis of the influence of key processes on the water yield and temperature of geothermal wells. Henan Water Resources \& South-to-North Water Diversion.2015;(20): 48-49(in Chinese).

Wang P, Xiang-H, Zhou-X. Well location deployment and reasonable well spacing shallow exploration. Chemical Enterprise Management.2018;25(4): 72(in Chinese).

Wen Q-B, Liang D-C, Xie L-K, et al. Review on model of wellbore temperature distribution during drilling. West-china Exploration Engineering.2007;19(11): 60-63(in Chinese).

Wu B S, Zhang X, Jeffrey R G. A model for downhole fluid and rock temperature prediction during circulation. Geothermics.2014;50(50):202-212.

Wang L, Peng X, Cao Y, et al. The prediction of wellbore fluid temperature distribution of geothermal production well. China Mining Magazine.2015;24(S1):376-380(in Chinese).

Wang F-Q, Cao J-H, Cao X-P, et al. Analysis of factors affecting fluidProduction mperature of porous sandstone geothermal wells in the tower.West-China Exploration Engineering.2018; 30(10):45-47(in Chinese).

Wang F, Zhang X-M, Zheng H-Z. Effect of pumping and irrigation wells arrangement groundwater flow field and temperature field. Building Technology Development.2016; 43(08): 31-35(in Chinese).

Wang G-S, Song X-Z, Shi Y, et al. Heat extraction analysis of a novel multilateral -well coaxial closed-loop geothermal system.Renewable Energy.2021;163: 974-986.

Xu Y-L, Jia C, Jia J-j, et al. Study on optimal arrangement of pumping and irrigation system for groundwater heat pump. Water Sciences and Engineering Technology.2017; (06):54-59(in Chinese).

Yoshioka M, Takakura S, Uchida Y. Estimation of groundwater flow from temperature monitoring in a borehole heat exchanger during a thermal response test. Hydrogeol J.2018; 26, 
853-867.

Yu J-Y. Research on the wellbore temperature for geothermal wells in Tibet[D]. 2013; Beijing: China University of Geosciences(in Chinese).

Zhu M, Duan Y-Z, Gao X-R, et al. Heat preservation suggestion and heatloss analysis of geothermal well. Science\&Technology Review.2015; 33(22) :32-36(in Chinese). 